\title{
Effects of transdermal testosterone on natriuretic peptide levels in women: a randomized placebo- controlled pilot study
}

\section{Citation}

Lin, Eleanor, Elizabeth McCabe, Christopher Newton-Cheh, Kenneth Bloch, Emmanuel Buys, Thomas Wang, and Karen K. Miller. 2012. "Effects of Transdermal Testosterone on Natriuretic Peptide Levels in Women: a Randomized Placebo-Controlled Pilot Study." Fertility and Sterility 97 (2) (February): 489-493. doi:10.1016/j.fertnstert.2011.11.001.

\section{Published Version}

doi:10.1016/j.fertnstert.2011.11.001

\section{Permanent link}

http://nrs.harvard.edu/urn-3:HUL.InstRepos:14229235

\section{Terms of Use}

This article was downloaded from Harvard University's DASH repository, and is made available under the terms and conditions applicable to Other Posted Material, as set forth at http:// nrs.harvard.edu/urn-3:HUL.InstRepos:dash.current.terms-of-use\#LAA

\section{Share Your Story}

The Harvard community has made this article openly available.

Please share how this access benefits you. Submit a story. 


\title{
Effects of Transdermal Testosterone on Natriuretic Peptide Levels in Women: A Randomized Placebo-Controlled Pilot Study
}

\author{
Eleanor Lin, MD1 ${ }^{1}$, Elizabeth McCabe, MS², Christopher Newton-Cheh, MD², Kenneth Bloch, \\ $\mathbf{M D}^{2,3}$, Emmanuel Buys, $\mathbf{P h D}^{3}$, Thomas Wang, $\mathbf{M D}^{2}$, and Karen K. Miller, $\mathbf{M D}^{1}$ \\ ${ }^{1}$ Neuroendocrine Unit, Massachusetts General Hospital and Harvard Medical School, Boston, MA \\ ${ }^{2}$ Cardiovascular Research Center, Cardiology Division, Massachusetts General Hospital and \\ Harvard Medical School, Boston, MA
}

${ }^{3}$ Anesthesia Center for Critical Care Research, Department of Anesthesia, Critical Care and Pain Medicine, Massachusetts General Hospital and Harvard Medical School, Boston, MA

\begin{abstract}
Objective-To investigate whether testosterone administration alters natriuretic peptide levels in women.

Design-Three-month, double-blind, randomized, placebo-controlled study.

Setting-Clinical research center.

Patients-51 women with hypoandrogenemia due to hypopituitarism.

Intervention-Transdermal testosterone (300 mcg daily) or placebo patch.

Main Outcome Measure-N-terminal pro-B-type natriuretic peptide (NT-proBNP) levels.

Results-NT-proBNP levels decreased in the transdermal testosterone group compared with placebo over three months $(p=0.009)$. The difference between groups remained significant after controlling for baseline age, systolic blood pressure, body mass index, and homeostasis model of assessment-insulin resistance $(p=0.008)$. Change in NT-proBNP over three months was inversely associated with change in free testosterone levels $(\rho=-0.41, p=0.01)$.
\end{abstract}

Conclusions-Testosterone administration to women results in decreased natriuretic peptide levels, suggesting that testosterone may be an inverse regulator of the natriuretic peptide system.

Clinical Trials Registration Number-NCT00027430

\section{Keywords}

Testosterone; natriuretic peptides

\footnotetext{
(C) 2011 American Society for Reproductive Medicine. Published by Elsevier Inc. All rights reserved.

Corresponding Author: Karen K. Miller, Neuroendocrine Unit, Bulfinch 457B, Massachusetts General Hospital, Boston, MA 02114, Tel: 617-726-3870, Fax: 617-726-5072, KKMiller@partners.org.

Conflicts of interest: The authors have no financial or other potential conflict of interest that could be perceived as prejudicing the impartiality of the research reported.

Publisher's Disclaimer: This is a PDF file of an unedited manuscript that has been accepted for publication. As a service to our customers we are providing this early version of the manuscript. The manuscript will undergo copyediting, typesetting, and review of the resulting proof before it is published in its final citable form. Please note that during the production process errors may be discovered which could affect the content, and all legal disclaimers that apply to the journal pertain.
} 


\section{INTRODUCTION}

Hypertension is more prevalent in men than in women of comparable age (1), but the mechanisms have not been fully elucidated. The natriuretic peptides are a family of cardiacderived hormones that have diuretic, natriuretic, and vasodilatory properties that have recently been implicated in the control of blood pressure in healthy adults (2). They also contribute to sodium homeostasis and cardiac remodeling. The cardiac natriuretic peptide system inhibits the renin-angiotensin system (RAAS), promotes natriuresis, and lowers blood pressure. Atrial natriuretic peptide (ANP) and B-type natriuretic peptide (BNP) are released in response to cardiac myocyte stretch, and both are synthesized in pro forms -- Nterminal proANP (NT-proANP) and N-terminal proBNP (NT-proBNP), respectively. Multiple population-based studies have shown that circulating natriuretic peptides are 60$80 \%$ higher in women than in men (3-7), suggesting a possible role for gonadal steroid regulation. A cross-sectional analysis of 682 pre-menopausal women from the Dallas Heart Study showed an inverse relationship between free $\mathrm{T}$ and natriuretic peptides (3). In another study, androgen deprivation in 43 men with prostate cancer resulted in increased natriuretic peptide levels (4). These data suggest that androgens may be important determinants of natriuretic peptide levels. However, this hypothesis has not been directly tested. Our study is the first to examine the effects of $\mathrm{T}$ on natriuretic peptide levels in women in a randomized, placebo-controlled study.

In this study, we investigated the effects of low-dose transdermal T replacement compared to placebo on natriuretic peptide levels in a group of women with androgen deficiency due to hypopituitarism. We hypothesized that transdermal $\mathrm{T}$ administration would result in a decrease in NT-proBNP levels compared with placebo and that the change in NT-proBNP levels would correlate with the change in free T levels.

\section{SUBJECTS AND METHODS}

\section{Subjects}

Study patients were recruited from advertisements and physician referrals from 2001 to 2004. Fifty-one women with hypopituitarism participated and were followed for 1 year. Inclusion criteria were ages 19 to 50 years, central hypogonadism and/or central hypoadrenalism, and free $\mathrm{T}$ below the median for healthy women of reproductive age. If subjects were hypogonadal, then estrogen replacement for at least one year prior to enrollment was a requirement of participation. All subjects had normal free T4 levels, and if receiving thyroid hormone replacement, then on stable doses for at least 3 months prior to study enrollment. Subjects had to be GH naïve or on stable doses of GH replacement for at least 2 years. Exclusion criteria have been previously stated (5) and included untreated hypopituitarism, pregnancy, breast-feeding, uncontrolled hypertension, contraindication to estrogen therapy, and exposure to exogenous androgens, dehydroepiandrosterone or supraphysiological glucocorticoid therapy within one year prior to enrollment.

\section{Protocol}

The protocol has been previously described elsewhere (5). Study subjects participated in a single-center, double-blind, randomized, placebo-controlled, parallel-group study, designed to determine the effects of transdermal $\mathrm{T}$ on bone density, body composition, cardiovascular risk markers, and neurobehavioral function in women with hypoandrogenism from hypopituitarism. T effects on these endpoints have been previously published, as have side effects, which were few, $(5,8)$ but effects of transdermal T on natriuretic peptide levels have not been previously reported. The primary endpoint was lumbar spine bone density at baseline, 1-month, and 3-months. The study was powered to have an $80 \%$ chance with $n=50$ 
to detect a difference in lumbar spine bone density between the groups (9) based on a standard deviation of 0.030 . The trial is registered at ClinicalTrials.gov, number NCT00027430.

The protocol was approved by the Partners Healthcare Institutional Review Board, and informed consent was obtained from all study subjects. The study was performed at the Massachusetts General Hospital General Clinical Research Center. After baseline testing, subjects were in blocks of 4, with stratification for prior GH use, to receive two $150 \mathrm{mcg} \mathrm{T}$ or placebo patches. Patches were packaged identically, and study subjects and research members involved with patient testing were kept blinded. The $150 \mathrm{mcg}$ patch delivers a mean dose of $150 \mathrm{mcg}$ of $\mathrm{T}$ daily, resulting in a mean time-averaged increment in serumfree $\mathrm{T}$ concentration of $2.7 \pm 0.9 \mathrm{pg} / \mathrm{mL}$ with a relatively constant free $\mathrm{T}$ level for 96 hours after patch application (6). Dose adjustments were made by a health care professional not involved with the study, and for every study subject on testosterone who experienced a dose adjustment, a study subject receiving placebo patches had concurrent "sham" dose adjustments to maintain blinding.

\section{Methods}

NT-proBNP levels were determined using a commercially available sandwich assay (Elecsys proBNP Assay, Roche Diagnostics, Indianapolis, Indiana) with total precision of $1.8-4.6 \%$ and a range of $5.00-35000 \mathrm{pg} / \mathrm{mL}$. In a study of 1,981 healthy blood donors (10), women aged 40 to 49 years had a median NT-proBNP of $50 \mathrm{pg} / \mathrm{mL}$ : the $10^{\text {th }}$ and $90^{\text {th }}$ percentiles were 20 and $116 \mathrm{pg} / \mathrm{mL}$. In a Framingham Heart Study cohort of 2,285 healthy subjects, the 2.5th and 97.5th percentiles for women aged 40-44 were 8.9 and $161.5 \mathrm{pg} / \mathrm{mL}$, respectively (11). Total $\mathrm{T}$ levels were determined using an immunoradiometric assay after column chromatography (Esoterix Endocrinology, Calabasas Hills, California) with a sensitivity of $3 \mathrm{ng} / \mathrm{dL}$, intraassay coefficient of variation less than $9 \%$, and lower limit of detection of $3 \mathrm{ng} / \mathrm{dL}(12)$. Percent free $\mathrm{T}$ was determined using equilibrium dialysis assay (Esoterix Endocrinology, Calabasas Hills, California) with a sensitivity of $0.1 \%$ and intraassay coefficient of variation of $6.9 \%$, and free $\mathrm{T}$ concentrations were calculated as the product of the total $\mathrm{T}$ and percent free $\mathrm{T}$, with a lower limit of detection of $0.10 \mathrm{pg} / \mathrm{mL}$ (12). Insulin-like growth factor-1 levels were determined using a RIA (Nichols Institute Diagnostics, San Clemente, CA) with a sensitivity of $14 \mathrm{ng} / \mathrm{mL}$ and intraassay coefficient of variation of 2.4-3.0\%. Total body water (TBW) was assessed by bioelectric impedance analysis (Bioelectrical Analyzer model BIA 101, RJL Systems, Michigan) (7). Homeostasis model of assessment-insulin resistance (HOMA-IR) was calculated using two hour oral glucose tolerance testing (13).

\section{Statistical Analysis}

The primary analysis was intention-to-treat. Undetectable hormone levels were assigned values just below the lower limit of detection. Data from subjects with NT-proBNP levels greater than $900 \mathrm{pg} / \mathrm{mL}$, indicative of heart failure, were excluded $(\mathrm{n}=1)$. Data were transformed by natural log prior to significance testing. Analysis of variance (ANOVA) was used to compare mean baseline clinical characteristics. Repeated measures ANOVA was used to determine the effects of randomization assignment on mean NT-proBNP, blood pressure, body mass index (BMI), TBW, and total and free $\mathrm{T}$ levels over the three-month period, and time $\times$ treatment interactions are reported. Univariate regression analysis was performed, and Spearman's rhos are reported. 


\section{RESULTS \\ Clinical Characteristics}

Clinical characteristics are presented in Table 1. At baseline, the two groups were of comparable age (range 19-50), blood pressure, BMI, TBW, fasting glucose, HOMA-IR, and gonadal steroid levels. The mean free $\mathrm{T}$ levels were $0.5 \pm 0.1 \mathrm{pg} / \mathrm{mL}$ in the placebo group and $0.7 \pm 0.2 \mathrm{pg} / \mathrm{mL}$ in the T group, with levels in all study subjects below the lower limit of the normal range (normal female range 1.1-6.3 pg/mL), and 55\% of the levels undetectable at baseline. The treatment group demonstrated a statistically significant increase in total and free $\mathrm{T}$ levels compared to placebo. Mean free $\mathrm{T}$ levels increased into the normal female range at 1 month and 3 months in the group randomized to $T$ (Table 1), consistent with $T$ replacement. Thirteen subjects were receiving antidepressants (6 in the placebo group and 7 in the T group) and nine were receiving antihypertensives ( 3 in the placebo group and 6 in the T group). There were no changes in blood pressure, BMI, or TBW in either group over the study period.

\section{Effects of Transdermal T on NT-proBNP Levels}

The mean NT-proBNP levels at baseline, 1 month, and 3 months in the two treatment groups are shown in Table 1. Mean pre-treatment NT-proBNP levels fell within the normal range for healthy females of similar age $(10,11)$. Over the 3-month study period, NT-proBNP levels significantly decreased in the treatment group compared with the placebo group (repeated measures ANOVA, time $\times$ treatment interaction $p=0.009$ ) (see Table 1). After excluding subjects with a change in antihypertensive therapy during the study period $(n=2$ in the placebo group and $n=1$ in the testosterone group), results remained significant (repeated measures ANOVA, time $\times$ treatment interaction $p=0.02$ ). The difference between groups remained significant after adjusting for age, systolic blood pressure, BMI, and HOMA-IR (adjusted repeated measures ANOVA, time $\times$ treatment interaction $p=0.008$ ).

\section{Associations with NT-proBNP}

Univariate regressions for NT-proBNP demonstrated that change in total $\mathrm{T}$ and free $\mathrm{T}$ over three months were inversely related to change in NT-proBNP levels, with total T Spearman's $\rho=-0.45, p=0.004$ and free T Spearman's $\rho=-0.41, p=0.01$ Figure 1).

\section{DISCUSSION}

In our study, low-dose transdermal $\mathrm{T}$ administration in a group of young women decreased natriuretic peptide levels compared to placebo. In addition, the changes in total and free $\mathrm{T}$ were inversely associated with change in NT-proBNP levels. This suggests that androgens may be a mediator of natriuretic peptide synthesis or secretion in women.

The natriuretic peptides play an important role in sodium homeostasis, regulation of vascular tone, and cardiac remodeling. Measurement of natriuretic peptide concentrations is used clinically for the assessment of patients with known or suspected heart failure (14). Levels are $60-80 \%$ higher in healthy women than in men (15-17). Moreover, there is a lower prevalence of cardiovascular disease and hypertension in pre-menopausal women than in men $(1,18)$. Additionally, genome-wide association studies have linked alleles associated with higher BNP levels with lower blood pressure, supporting a role for these peptides in chronic blood pressure regulation $(2,16)$. While the gender dichotomy in natriuretic peptides may contribute to the hypertension and cardiovascular disease risk, the mechanism for the differing level of natriuretic peptides is not known. 
Animal and human data suggest that gonadal steroids may be important determinants of natriuretic peptide levels, but the animal data are contradictory and the human data largely cross-sectional or uncontrolled. Animal data have shown that gonadal steroids affect natriuretic peptide levels, but the direction of this interaction is not clear. In orchiectomized rats, atrial and plasma ANP levels increase. When T is administered to these orchiectomized rats, plasma ANP levels decrease and are similar to male controls (19). Similar studies in female rats showed that ovariectomized rats have decreased atrial ANP-messenger RNA levels, and E2 administration increases atrial ANP-messenger RNA levels (20). However, in the same study, $\mathrm{T}$ administration to castrated rats resulted in increased atrial ANP-messenger RNA levels (20). In spontaneously hypertensive rats, orchiectomy attenuated the elevation in systolic blood pressure, and $\mathrm{T}$ administration restored the increase in systolic blood pressure (21), suggesting a role for $\mathrm{T}$ in the regulation of blood pressure, but natriuretic peptide levels were not measured.

Human data have also suggested that gonadal steroids may affect natriuretic peptide levels. Three non-placebo-controlled studies of postmenopausal women randomized to various forms of estrogen/progestin replacement therapy showed that natriuretic peptide levels increased compared with pretreatment levels (22-24). The effects of androgens on the natriuretic peptide system have also been studied, but not in randomized, placebo-controlled studies. A cross-sectional analysis of 683 pre-menopausal women showed an inverse relationship between free $\mathrm{T}$ and natriuretic peptides (3). In another study of 43 men with prostate cancer, NT-proBNP levels increased with androgen deprivation (4). Although there are few data on the effects of testosterone on natriuresis, testosterone administration, in higher male doses, results in an increase in fluid retention (25). These studies suggest that gonadal steroids may affect the natriuretic peptide system, with estrogens and/or progestins increasing, and androgens decreasing, levels. Our randomized, placebo-controlled study demonstrates that low-dose $\mathrm{T}$ at replacement doses, i.e. at levels relevant to female physiology, decrease natriuretic peptide levels in women.

We chose to focus on the natriuretic peptides given the growing interest in the interaction of this axis with gonadal steroids (26) and the link between this axis and long-term blood pressure regulation (2). For the present study, we opted to measure NT-proBNP. NTproBNP concentrations are highly correlated with both mature BNP and NT-proANP (2). Furthermore, we have documented strong cross-sectional associations between NT-proBNP (using the same assay as in the present study) and hormonal status in an epidemiologic cohort (26). Although c-terminal ANP and BNP are the biologically active peptides, they are less practical for measurement in ambulatory studies, for several reasons. Robust, commercially-available assays for mature ANP do not presently exist, and in healthy individuals, circulating BNP is frequently below the detection limit of available assays.

A limitation of our study is the heterogeneity of our study subjects who, despite being generally healthy other than having hypopituitarism, were receiving multiple hormone replacement therapies, some of which can affect salt and water balance. However, administration of relatively high doses of $\mathrm{T}$ to women who are not hypogonadal would have resulted in supraphysiologic androgen levels which may cause side effects in young women and therefore is impractical. In contrast, hypopituitarism is a physiologic model of relative hypoandrogenism that provides an opportunity to investigate the effects of $\mathrm{T}$ administration without exposing volunteers to supraphysiologic $\mathrm{T}$ levels. In addition, in order to minimize variability, we required study participants to be receiving stable replacement doses before study entry, which should have minimized the longitudinal effects of these medications, and we confirmed that total body water, as measured by BIA, did not change during the study. Moreover, the value of a prospective, randomized, placebo-controlled design is that confounding by such effects should be minimized by randomization. Another limitation of 
the study is its short duration of three months. Therefore, conclusions regarding long-term effects of androgens are not warranted. It is also noted that blood pressure did not change after $\mathrm{T}$ administration in our study. Given the size of the study, we were likely underpowered to detect changes in blood pressure. Twenty-four hour blood pressure monitoring may be necessary to detect differences in blood pressure among small groups of young women (27). In addition, longer exposure to androgens may be necessary to induce ambulatory hypertension. Finally, other systems, such as RAAS, may also contribute to observed hemodynamic responses, and we did not assess these systems.

\section{CONCLUSIONS}

Administration of low doses of transdermal T to women resulted in decreased NT-proBNP levels compared with placebo. Therefore, androgens may be important regulators of the natriuretic peptide system in women. Further studies are warranted to investigate whether the lower androgen levels in women compared with men may explain the gender dimorphism in natriuretic peptide levels and contribute to the protective effects of female sex on the incidence of hypertension and cardiovascular risk.

\section{Acknowledgments}

Financial Support: This work was supported by Food and Drug Administration grant FD-R-001981 and National Institutes of Health grants M01-RR-01066 and T32-DK-007028-36. Procter and Gamble Pharmaceuticals provided study medication and placebo only.

\section{References}

1. Kuroski de Bold ML. Estrogen, natriuretic peptides and the renin-angiotensin system. Cardiovasc Res. 1999; 41:524-31. [PubMed: 10435024]

2. Newton-Cheh C, Larson MG, Vasan RS, Levy D, Bloch KD, Surti A, et al. Association of common variants in NPPA and NPPB with circulating natriuretic peptides and blood pressure. Nat Genet. 2009; 41:348-53. [PubMed: 19219041]

3. Chang AY, Abdullah SM, Jain T, Stanek HG, Das SR, McGuire DK, et al. Associations among androgens, estrogens, and natriuretic peptides in young women: observations from the Dallas Heart Study. J Am Coll Cardiol. 2007; 49:109-16. [PubMed: 17207730]

4. Dockery F, Bulpitt CJ, Agarwal S, Vernon C, Nihoyannopoulos P, Kemp M, et al. Anti-androgens increase N-terminal pro-BNP levels in men with prostate cancer. Clin Endocrinol (Oxf). 2008; 68:59-65. [PubMed: 17692108]

5. Miller KK, Biller BM, Beauregard C, Lipman JG, Jones J, Schoenfeld D, et al. Effects of testosterone replacement in androgen-deficient women with hypopituitarism: a randomized, doubleblind, placebo-controlled study. J Clin Endocrinol Metab. 2006; 91:1683-90. [PubMed: 16478814]

6. Mazer NA, Shifren JL. Transdermal testosterone for women: a new physiological approach for androgen therapy. Obstet Gynecol Surv. 2003; 58:489-500. [PubMed: 12832941]

7. Lukaski HC. Methods for the assessment of human body composition: traditional and new. Am J Clin Nutr. 1987; 46:537-56. [PubMed: 3310598]

8. Miller KK, Biller BM, Schaub A, Pulaski-Liebert K, Bradwin G, Rifai N, et al. Effects of testosterone therapy on cardiovascular risk markers in androgen-deficient women with hypopituitarism. J Clin Endocrinol Metab. 2007; 92:2474-9. [PubMed: 17426086]

9. Davis SR, McCloud P, Strauss BJ, Burger H. Testosterone enhances estradiol's effects on postmenopausal bone density and sexuality. Maturitas. 1995; 21:227-36. [PubMed: 7616872]

10. Hess G, Runkel S, Zdunek D, Hitzler WE. N-terminal pro-brain natriuretic peptide (NT-proBNP) in healthy blood donors and in patients from general practitioners with and without a diagnosis of cardiac disease. Clin Lab. 2005; 51:167-72. [PubMed: 15819172] 
11. Fradley MG, Larson MG, Cheng S, McCabe E, Coglianese E, Shah RV, et al. Reference Limits for N-Terminal-pro-B-Type Natriuretic Peptide in Healthy Individuals (from the Framingham Heart Study). Am J Cardiol. 2011; 108:1341-5. [PubMed: 21864812]

12. Miller KK, Rosner W, Lee H, Hier J, Sesmilo G, Schoenfeld D, et al. Measurement of free testosterone in normal women and women with androgen deficiency: comparison of methods. J Clin Endocrinol Metab. 2004; 89:525-33. [PubMed: 14764757]

13. Matthews DR, Hosker JP, Rudenski AS, Naylor BA, Treacher DF, Turner RC. Homeostasis model assessment: insulin resistance and beta-cell function from fasting plasma glucose and insulin concentrations in man. Diabetologia. 1985; 28:412-9. [PubMed: 3899825]

14. de Lemos JA, McGuire DK, Drazner MH. B-type natriuretic peptide in cardiovascular disease. Lancet. 2003; 362:316-22. [PubMed: 12892964]

15. Loke I, Squire IB, Davies JE, Ng LL. Reference ranges for natriuretic peptides for diagnostic use are dependent on age, gender and heart rate. Eur J Heart Fail. 2003; 5:599-606. [PubMed: 14607197]

16. Redfield MM, Rodeheffer RJ, Jacobsen SJ, Mahoney DW, Bailey KR, Burnett JC Jr. Plasma brain natriuretic peptide concentration: impact of age and gender. J Am Coll Cardiol. 2002; 40:976-82. [PubMed: 12225726]

17. Wang TJ, Larson MG, Levy D, Leip EP, Benjamin EJ, Wilson PW, et al. Impact of age and sex on plasma natriuretic peptide levels in healthy adults. Am J Cardiol. 2002; 90:254-8. [PubMed: 12127613]

18. Schenck-Gustafsson K. Risk factors for cardiovascular disease in women: assessment and management. Eur Heart J. 1996; 17 (Suppl D):2-8. [PubMed: 8869875]

19. Hwu CM, Tsai SC, Lau CP, Pu HF, Wang TL, Chiang ST, et al. Increased concentrations of atrial and plasma atrial natriuretic peptide in castrated male rats. Life Sci. 1993; 52:205-12. [PubMed: 8355561]

20. Hong M, Yan Q, Tao B, Boersma A, Han KK, Vantyghem MC, et al. Estradiol, progesterone and testosterone exposures affect the atrial natriuretic peptide gene expression in vivo in rats. Biol Chem Hoppe Seyler. 1992; 373:213-8. [PubMed: 1534483]

21. Chen YF, Meng QC. Sexual dimorphism of blood pressure in spontaneously hypertensive rats is androgen dependent. Life Sci. 1991; 48:85-96. [PubMed: 1986184]

22. Maffei S, Del Ry S, Prontera C, Clerico A. Increase in circulating levels of cardiac natriuretic peptides after hormone replacement therapy in postmenopausal women. Clin Sci (Lond). 2001; 101:447-53. [PubMed: 11672449]

23. Karjalainen AH, Ruskoaho H, Vuolteenaho O, Heikkinen JE, Backstrom AC, Savolainen MJ, et al. Effects of estrogen replacement therapy on natriuretic peptides and blood pressure. Maturitas. 2004; 47:201-8. [PubMed: 15036490]

24. Kawano H, Nagayoshi Y, Soejima H, Tanaka Y, Hokamaki J, Miyamoto S, et al. B-type natriuretic peptide after hormone therapy in postmenopausal women with chest pain and normal coronary angiogram. Menopause. 2008; 15:352-6. [PubMed: 18090872]

25. Johannsson G, Gibney J, Wolthers T, Leung KC, Ho KK. Independent and combined effects of testosterone and growth hormone on extracellular water in hypopituitary men. J Clin Endocrinol Metab. 2005; 90:3989-94. [PubMed: 15827107]

26. Lam CS, Cheng S, Choong K, Larson MG, Murabito JM, Newton-Cheh C, et al. Influence of sex and hormone status on circulating natriuretic peptides. J Am Coll Cardiol. 2011; 58:618-26. [PubMed: 21798425]

27. Holte J, Gennarelli G, Berne C, Bergh T, Lithell H. Elevated ambulatory day-time blood pressure in women with polycystic ovary syndrome: a sign of a pre-hypertensive state? Hum Reprod. 1996; 11:23-8. [PubMed: 8671152] 


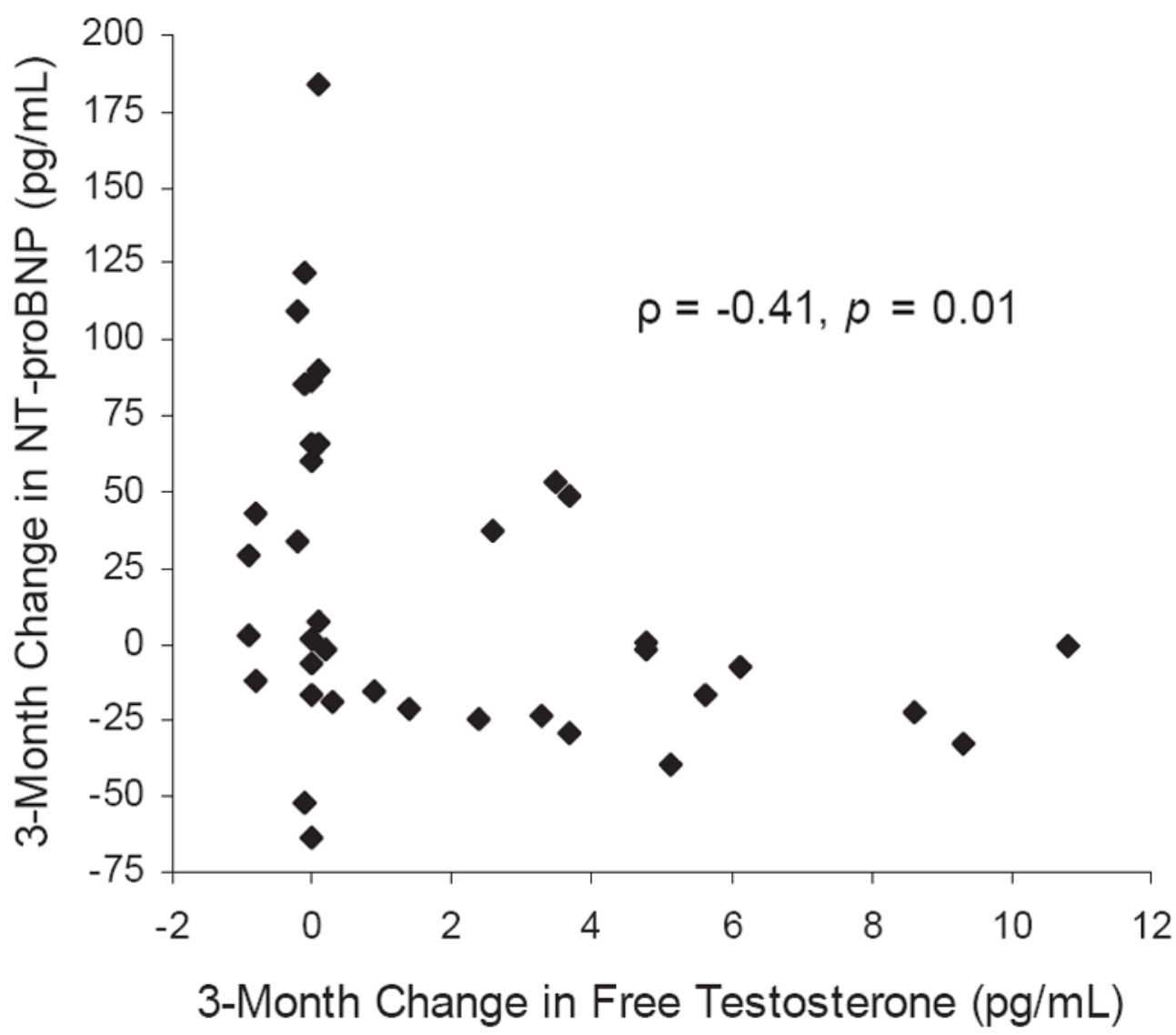

Figure 1.

Three-month change in NT-proBNP levels versus 3-month change in free T levels. Spearman's rho $=-0.41$ and $p=0.01$. 


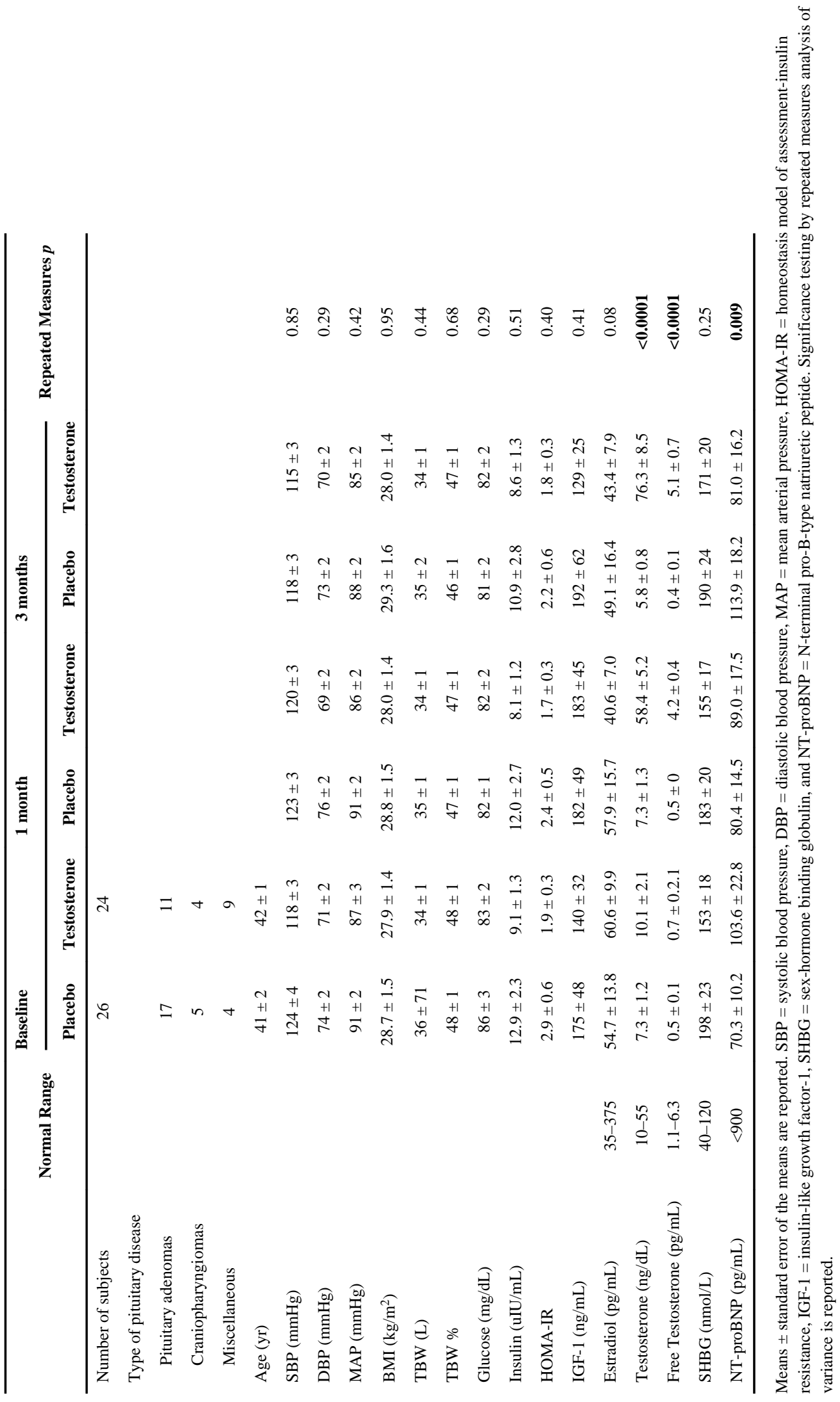

